\author{
Research Article \\ www.ijrap.net (ISSN:2229-3566)
}

\title{
AN EXPERIMENTAL STUDY TO EVALUATE CARDIOPROTECTIVE ACTIVITY OF JINGINI LANNEA COROMANDELICA MERR (HOUTT): AN IN VIVO STUDY
}

\author{
Rachana K. L. ${ }^{* 1}$, Giri Prashanth K.G ${ }^{2}$, Manjunatha P. Mudagal ${ }^{3}$, Seema Pradeep ${ }^{4}$, Yashaswini B.K ${ }^{1}$, Varuni B.G. ${ }^{1}$ \\ ${ }^{1}$ PG Scholar, Department of PG studies in Dravya guna Karma Vijnana, Sri Sri College of Ayurvedic Science and \\ Research Hospital, Bangalore, Karnataka, India \\ ${ }^{2}$ Professor and Guide, Department of PG Studies in Dravya guna Karma Vijnana, Sri Sri College of Ayurvedic Science \\ and Research Hospital, Bangalore, Karnataka, India \\ ${ }^{3}$ HOD and Co-guide, Department of Pharmacology, Acharya and BM Reddy College of Pharmacy, Hesaraghatta, \\ Bangalore, Karnataka, India \\ ${ }^{4}$ HOD, Department of PG Studies in Dravya guna Karma Vijnana, Sri Sri College of Ayurvedic Science and Research \\ Hospital, Bangalore, Karnataka, India
}

Received on: 06/10/20 Accepted on: 16/11/20

\author{
*Corresponding author \\ E-mail: dr.klr.lucky@gmail.com
}

DOI: 10.7897/2277-4343.1106182

\begin{abstract}
Jingini - Lannea coromandelica Merr. (Houtt) is mentioned in Bhava Prakasha Nighantu and Bhavamishra advocates JINGINI for Hridroga. An experimental study was designed with a Model - Isoproterenol (ISO) Induced Cardiac toxicity in order to prove the efficacy of JINGINI for its Cardioprotective activity. Animals were administered with Aqueous and Methanolic extract of JINIGINI in higher and lower dose. The Acute toxicity studies were conducted up to $5000 \mathrm{mg} / \mathrm{kg}$ body weight in accordance with OECD 425 guidelines. The higher dose calculated from $1 / 5^{\text {th }}$ of $5000 \mathrm{mg} / \mathrm{kg}$ body weight which summed up to $1000 \mathrm{mg} / \mathrm{kg}$ body weight and lower dose calculated from $1 / 10^{\text {th }}$ of $5000 \mathrm{mg} / \mathrm{kg}$ body weight was concluded as 500 $\mathrm{mg} / \mathrm{kg}$ body weight. The Methanolic extract of JINGINI in Higher and Lower dose ( $1000 \mathrm{mg} / \mathrm{kg}$ body weight and $500 \mathrm{mg} / \mathrm{kg}$ body weight respectively) was found to be efficacious in providing the Cardio-protective action in SD Rats.
\end{abstract}

Keywords: Jingini, Cardioprotective activity, Isoproterenol (ISO)

\section{INTRODUCTION}

Classical Ayurveda elaborates on Hridaya (Heart) and the pathologies related to it systematically with the dedication of various chapters in Bruhatrayi and Laghutrayi. The other medieval period treatises describe Hridroga with its treatment aspects. Bhavamishra has indicated JINGINI in Hridroga in Vatadi varga of Bhava Prakasha Nighantu. ${ }^{1}$

Hridaya is an organ which draws blood from different parts of the body and in turn supplies it to different parts of the body (haharati/to receive from, da-dadaati/to give, ya-yagati/to control). It is one of the important Marma and Pranayatanas. It is the Moola Sthaanafor Rasa and Raktavaha srotas. Embryologically, Hridaya originates from the Sara Bhaga of Rakta Dhatu and Kapha Dosha. The shape of the heart is mentioned as Inverted Lotus. Most importantly Hridaya is the Sthaana for Udaaba Vata, Vyaana Vata, Praana Vata, Sadhaka Pitta, Avalambaka Kapha and Ojas. It is also elucidated that Hridaya is Sthaana for Praana, Buddhi, Manas. $^{2}$

The concept of Hridya is well described in Classics. Acharya Charaka ornated Hridaya Mahakashaya varga elaborating it as Cardiac tonic drugs which are meant to improvise and strengthen the Heart through its structure and function and catalyzes the maintenance of Cardiac health.

We not only find references of Hridroga in separate dedicated chapters but also, we find Hridroga mentioned as Lakshana in certain diseases. In Vataja Kasa; Hrut shoola is one of the
Lakshana. In Kshayaja kasa "Hrudayam Manyatecchyutam" meaning the rogi of Kshayaja Kasa feels as though his heart is falling down and will be displaced from its actual position. Most importantly the Classical formulations mentioned for different types of Kasa out of which few are also indicated for Hridroga (e.g. Pippalyadi ghrita etc.). ${ }^{3}$

Ischemic heart disease and stroke are the predominant causes and are responsible for $>80 \%$ of CVD deaths. The Global Burden of Disease study estimate of age-standardized CVD death rate of 272 per 100000 population in India is higher than the global average of 235 per 100000 population. ${ }^{4}$ Cardio- protection includes all the mechanism and means that contribute to the preservation of heart by reducing or even preventing Myocardial damage. Cardiovascular disease (CVD) remains the principal cause of death in both developed and developing countries. CVD includes High blood pressure, Coronary heart disease, Congestive heart failure, Stroke and account to Myocardial Infarction which causes interruption of blood supply to apart of the heart leading heart cells to die, commonly due to blockage of coronary artery. Cardio-vascular deaths remain the leading cause of death in India. Therefore, finding ways to reduce the mortality of Cardiovascular disease remains an important health goal.

Herbal drugs are known to exhibit creditable medicinal properties for the treatment of heart ailments and need to be explored for its potential application in prevention and therapy of human ailments. More than 2000 plants have been listed in the Traditional (Herbal/Alternative) systems of medicine and some of these are providing comprehensive relief to the people 
suffering from cardio-vascular diseases, specially "hyperlipidaemia" and "ischemic heart disease". WHO reports indicate that around eighty percent of the global population still relies on botanical drugs and several herbal medicines have advanced to clinical use in modern times ${ }^{5}$

Henceforth a study has been taken up in order to evaluate the efficacy of an Herbal drug - Jingini - Lannea coromandelica Merr (Houtt) in Heart disorders using related Animal models.

\section{MATERIAL AND METHODS}

\section{Preparation of the Plant Source}

\section{Collection of the Trial drug}

The Stem Bark of Jingini collected in Sharad Ritu ( $1^{\text {st }}$ week of December 2018) from Brahmavara Forest, UDUPI, Karnataka.

\section{Drug Authentication}

The genuineness of the Stem Bark of Jingini confirmed and authenticated by DR. Shiva Manjunath, Ph.D., senior scientist (Bot), Department of Dravya guna, Sri Sri College of Ayurvedic Science and Research, Bangalore.

\section{Preparation of the Drug}

The Stem Bark of Jingini was washed under tap water and was kept for shade drying in Dravya guna Laboratory of Sri Sri College of Ayurvedic Science and Research, Bangalore. The water and moisture content was removed before weighing it. Later it was kept for Shade drying for 30 days. Once the drug was completely dried, the dry weight of the drug was noted. The dried drug was coarse powdered by using the Pulveriser and sieved using Mesh no: 60 in Department of Rasa Shastra and Bhaishajya Kalpana Laboratory, Sri Sri College of Ayurvedic Science and Research, Bangalore. Powdered drug was stored in Amber glass air tight container for the purpose of preparation of Extracts.

\section{Place of the Study}

The Experimental study was carried out in Department of Pharmacology, Acharya and BM Reddy College of Pharmacy, Hesaraghatta, Bangalore.

\section{Ethical Clearance}

The Experimental procedure was carried out in accordance with the ethical guidelines for animals proposed by CPCSEA, Government of India. Ethical clearance was obtained from Department of Pharmacology, Acharya and BM Reddy College of Pharmacy, Bangalore as per the protocol outlined in publication of the committee for the purpose of control and supervision of Experiments on animals' standard guidelines (CPCSEA) and approval was obtained from Institutional Animal Ethics committee (IAEC) with reference no: IAEC/ABMRCP/2019-2020/11.

\section{Source and Selection of Animals}

Healthy Sprague Dawley Rats weighing 140-200 g were procured from Acharya and BM Reddy College of Pharmacy.

\section{Toxicity study (For Dose Fixation)}

\section{Acute Oral Toxicity Study}

The toxicity study of Aqueous and Methanolic extract of Stem Bark of JINGINI - Lannea coromandelica Merr. (Houtt) was carried out in accordance with OECD guidelines 425 for limit test.

\section{Fundamentals of Limit test}

The limit test is primarily used in situation where the experiment has prior information indicating that the material to be tested is likely to be non-toxic that is having toxicity only above regulatory limit doses. Thus, it allows the starting dose of $2000 \mathrm{mg} / \mathrm{kg}$ and also $5000 \mathrm{mg} / \mathrm{kg}$. The limit test is a sequential test that uses a maximum of 4 animals.

\section{Modus Operandi for Toxicity Study}

Nulliparous, non-pregnant and 8 to 12 weeks old female rats weighing around 140-200 grams were used.

A single dose of Aqueous and Methanolic extract of Stem bark of JINGINI- Lannea coromandelica Merr. (Hout) $(2000 \mathrm{mg} / \mathrm{kg}$ body weight) was administrated to two of the animals respectively included in the study.

A single dose of Aqueous and Methanolic extract of Stem bark of JINGINI- Lannea coromandelica Merr. (Hout) $(5000 \mathrm{mg} / \mathrm{kg}$ body weight) was administrated to two of the animals respectively included in the study.

Based on animals survived or died, suitable test was performed (if died, main test was performed and if survived, same test was continued with remaining animals).

The animal was observed continuously for 2 hours under following profile;

\section{Behavioral Profile}

Spontaneous, Restlessness, Irritability and Fearfulness

\section{Neurological Profile}

Spontaneous activity, Reactivity, Touch response, Pain response and Gait

\section{Autonomic Profile}

Defecation and Urination

After a period of 24 and 72 hours they were observed for any lethality or death. If toxic signs of lethality are not observed, then $1 / 5^{\text {th }}, 1 / 10^{\text {th }}$, part of the limit test dose was considered as test doses for present study.

\section{Dose of the Trial Drug}

High Dose and Lower Dose of Aqueous and Methanolic extract of Jingini was concluded as $1000 \mathrm{mg} / \mathrm{kg}$ body weight and 500 $\mathrm{mg} / \mathrm{kg}$ body weight respectively. 


\section{Route of Administration}

The drugs were administered orally through Rat gauging needle no 24 .

\section{Preparation of Dosage}

The dosage was calculated based on the body weight of the Sprague Dawley Rats (SD Rats). The Aqueous and Methanolic extract of the drug was prepared in the ratio 1:1 (e.g. For 1 gram of drug $1 \mathrm{ml}$ of distilled water was added) in order to prepare concentrated drug dosage. Total amount of extract required per day was calculated including the volume of distilled water which was finely triturated using Mortar and Pestle to which 2\% gum acacia was also added in order to ensure the uniformity in the preparation. Such prepared solution was administered orally using Gastric cannula.?

\section{Preparation of Isoproterenol for Inducing Toxicity (For Cardio protective Activity)}

A stock solution was prepared with $0.1 \mathrm{~g}$ of Isoproterenol which was added on to $10 \mathrm{ml}$ of Distilled water which was stirred well in volumetric flask in order to obtain a Homogenous mixture. The dosage of $80 \mathrm{mg} / \mathrm{kg}$ body weight was administered subcutaneously to Sprague Dawley Rats of 5 groups (Disease control, aqueous high and low dose, Methanolic High and low dose) in accordance with body weight of the animals on $31^{\text {st }}$ day. On $32^{\text {nd }}$ day $60 \mathrm{mg} / \mathrm{kg}$ body weight, Isoproterenol was induced subcutaneously to Sprague Dawley Rats of 5 groups (Disease control, aqueous high and low dose, Methanolic High and low dose) in accordance with body weight of the animals. The Rats were observed for their Mortality and Behavioral profile for 48 hours. ${ }^{7}$

\section{Inclusion criteria}

- Healthy Sprague Dawley (SD) Rats of either sex.

- Sprague Dawley Rats weighing 140- 200 g.

\section{Exclusion criteria}

- SD rats which are pregnant.

- SD rats showing the signs of infection before or during the course of study.

- SD rats those who are under other experiments.

- SD rats younger than 45 days.

\section{Grouping}

Method Adopted: Isoproterenol induced Cardiac Toxicity Model

\begin{tabular}{|c|c|c|}
\hline Group & Drug Used & No. of Rats \\
\hline G1 & Control group & 06 \\
\hline G2 & Disease control group & 06 \\
\hline G3 & Aqueous Extract of Stem Bark of JINGINI-Lannea coromandelica Merr. (Houtt) $-1000 \mathrm{mg} / \mathrm{kg}$ body weight & 06 \\
\hline G4 & Aqueous Extract of Stem Bark of JINGINI- Lannea coromandelica Merr. (Houtt) $-500 \mathrm{mg} / \mathrm{kg} \mathrm{body} \mathrm{weight}$ & 06 \\
\hline G5 & Methanolic Extract of Stem Bark of JINGINI- Lannea coromandelica Merr.(Houtt)- $1000 \mathrm{mg} / \mathrm{kg} \mathrm{body} \mathrm{weight}$ & 06 \\
\hline G6 & Methanolic Extract of Stem Bark of JINGINI- Lannea coromandelica Merr.(Houtt)- $500 \mathrm{mg} / \mathrm{kg}$ body weight & 06 \\
\hline
\end{tabular}

\section{Treatment Protocol}

Screening Method of the Model: Isoproterenol (ISO) induced Cardiac Toxicity Model was used to assess the Cardio-protective ability of Stem Bark of Jingini-Lannea coromandelica Merr. (Houtt)

Animals were divided into Six groups consisting of six animals in each kept in Rat cages for the entire duration of experiment. All the animals had free access to regular rat chow and drinking water ad libitum.

Group 1 serves as Normal control group receiving regular Rat food and Drinking water.

Group 2 is Disease control receiving regular Rat food and Drinking water along with only Isoproterenol (ISO) being induced on $31^{\text {st }}$ and $32^{\text {nd }}$ day of the experiment.

Group 3 \& Group 4 receiving high dose $(1000 \mathrm{mg} / \mathrm{kg}$ body weight) and Low dose (500 $\mathrm{mg} / \mathrm{kg}$ body weight) respectively, serves as Treatment group of aqueous extract of Stem Bark of Jingini-Lannea coromandelica Merr. (Houtt) along with Isoproterenol $80 \mathrm{mg} / \mathrm{kg}$ body weight on $31^{\text {st }}$ day and $60 \mathrm{mg} / \mathrm{kg}$ body weight on $32^{\text {nd }}$ day was administered Sub-cutaneously.

Group 5 \& Group 6 serves as Treatment groups of Methanolic extract of Stem Bark of Jingini - Lannea coromandelica Merr. (Houtt) receiving High dose (1000 $\mathrm{mg} / \mathrm{kg}$ body weight) and Low dose $(500 \mathrm{mg} / \mathrm{kg}$ body weight) respectively serves as Treatment groups of Alcoholic extract of Stem Bark of Jingini - Lannea coromandelica Merr. (Houtt) along with Isoproterenol $80 \mathrm{mg} / \mathrm{kg}$ body weight on $31^{\text {st }}$ day and $60 \mathrm{mg} / \mathrm{kg}$ body weight on $32^{\text {nd }}$ day was administered Sub-cutaneously.

\section{Assessment of Cardio-protective Activity}

\section{Serum Analysis}

After the experimental period, blood was collected from retroorbital plexus under light Ether anesthesia condition, using Glass capillaries and blood was collected in $10 \mathrm{ml}$ EDTA tubes. Serum was separated from blood obtained through Centrifugation at $5000 \mathrm{rpm}$ for $20 \mathrm{~min}$. The obtained serum was pipette to Eppendorf tubes and was stored in -20 degree Celsius, until further Biochemical parameters were analyzed. The Serum was analyzed for;

- Cardiac markers (CK-MB and LDH)

- Lipid profile (Triglycerides, Total Cholesterol, HDL)

- Liver Function test (SGOT, SGPT, Total Bilirubin, Albumin, Total Protein)

- Renal Function test (Urea, Creatinine)

\section{Histopathological Analysis of the Heart}

In each group the animals were sacrificed and were dissected in order to collect the Heart. Every group, one animal's Heart was separated and was washed with clean water and then in Buffer Solution and was stored in Formalin filled containers in order to 
protect Heart from decomposition prior to histopathological study.

\section{Statistical Analysis}

The results were presented as a Mean \pm Standard Error of the Mean. The difference among data was statistically analyzed using one- way ANOVA \& Dunnett's test.

\section{RESULT}

\section{Observations of Acute Toxicity Study}

Acute oral toxicity studies revealed that there is no toxicity and mortality of the Sprague Dawley rats administered with Aqueous and Methanolic extract of Stem Bark of Jingini-Lannea coromandelica Merr. (Houtt) up to $5000 \mathrm{mg} / \mathrm{kg}$ body weight even after 14 days of observation after the administration of the drug dose (Table 1 and 2)

\section{Statistical Analysis of the Biochemical Parameters}

\section{Cardiac Marker}

\section{CK-MB}

Results of effect of plant extracts on cardiac markers are presented in Figure 1 CK-MB values were found to be $68.3 \pm 21.3$ $\mathrm{IU} / \mathrm{L}$ in the disease control group subjected to ISO. Significant increase in CK-MB levels was observed in Group 2 when compared against Group 1. Aqueous and Methanolic plant extracts of Jingini at different dosages offered significant $(\mathrm{P}<$ $0.01)$ dose dependent cardio-protection as evidenced by reversing CK-MB levels.

\section{LDH}

Results of plant extracts on cardiac markers are presented in the Figure 2. LDH values were found to be $1084 \pm 466 \mathrm{IU} / \mathrm{L}$ in the disease control group subjected to ISO. Significant increase in LDH levels was observed in Group 2 when compared against Group 1. Aqueous and Methanolic plant extracts of Jingini at different dosages offered significant $(\mathrm{P}<0.01)$ dose dependent cardio-protection as evidenced by reversing LDH levels.

\section{Lipid Profile}

\section{HDL}

Results of effect of plant extract on HDL levels are presented in Figure 3. HDL values were found to be $15.33 \pm 11.219 \mathrm{mg} / \mathrm{dl}$ in disease control group subjected to ISO. Significant decrease in HDL levels was observed in Group 2 when compared against Group 1. Aqueous and Methanolic Plant extracts of Jingini at different dosages offered significant $(\mathrm{P}<0.01)$ dose dependent cardio-protection as evidenced by increased HDL levels.

\section{Cholesterol}

Results of effect of plant extract on Cholesterol levels are presented in Figure 4. Cholesterol levels were found to be $255 \pm$ $33.764 \mathrm{mg} / \mathrm{dl}$ in the disease control group subjected to ISO. Significant increase in Cholesterol levels was observed in Group 2 when compared against Group 1. Aqueous and Methanolic plant extracts of Jingini at different dosages offered significant $(\mathrm{P}$ $<0.001)$ dose dependent cardio-protection as evidenced by stabilized Cholesterol levels.

\section{Triglycerides}

Results of effect of plant extract on Cholesterol levels are presented in Figure 5. Triglycerides levels were found to be $187.83 \pm 49.4 \mathrm{mg} / \mathrm{dl}$ in the disease control group subjected to ISO. Significant increase in Triglyceride levels was observed in Group 2 when compared against Group 1. Aqueous and Methanolic plant extracts of Jingini at different dosages offered significant ( $\mathrm{P}$ $<0.001$ ) dose dependent cardio-protection as evidenced by stabilized triglycerides levels.

\section{Liver Function Tests (LFT)}

\section{SGPT}

Results of effect of plant extract on SGPT levels are presented in Figure 6. SGPT levels were found to be $47.67 \pm 1.67 \mathrm{mg} / \mathrm{dl}$ in the disease control group subjected to ISO. Significant increase in SGPT levels was observed in Group 2 when compared against Group 1. Aqueous and Methanolic plant extracts of Jingini at different dosages offered significant $(\mathrm{P}<0.001)$ dose dependent cardio-protection as evidenced by negligible SGPT levels.

\section{SGOT}

Results of effect of plant extract on SGOT levels are presented in Figure 7. SGOT levels were found to be $51.83 \pm 15.510 \mathrm{mg} / \mathrm{dl}$ in the disease control group subjected to ISO. Significant increase in SGOT levels was observed in Group 2 when compared against Group 1. Aqueous and Methanolic plant extracts of Jingini at different dosages offered significant $(\mathrm{P}<0.001)$ dose dependent cardio-protection as evidenced by negligible SGOT levels.

\section{Bilirubin}

Results of effect of plant extract on Bilirubin levels are presented in Figure 8. Bilirubin levels were found to be $2.22 \pm 2.93 \mathrm{mg} / \mathrm{dl}$ in the disease control group subjected to ISO. Significant increase in Bilirubin levels was observed in Group 2 when compared against Group 1. Aqueous and Methanolic plant extracts of Jingini at different dosages offered significant $(\mathrm{P}<0.001)$ dose dependent cardio-protection as evidenced by decreased Bilirubin levels.

\section{Renal Function Test: (RFT)}

\section{Creatinine}

Results of effect of plant extract on creatinine levels are presented in Figure 9. Creatinine levels were found to be $1.50 \pm 0.663 \mathrm{mg} / \mathrm{dl}$ in the disease control group subjected to ISO. Significant increase in creatinine levels was observed in Group 2 when compared against Group 1. Aqueous and Methanolic plant extracts of Jingini at lower dosages offered significant $(\mathrm{P}<0.001)$ cardioprotection as evidenced by decreased creatinine levels.

\section{Total Protein}

Results of effect of plant extract on Protein levels are presented in Figure 10. Protein levels were found to be $12.03 \pm 3.447 \mathrm{mg} / \mathrm{dl}$ in the disease control group subjected to ISO. Significant increase in Protein levels was observed in Group 2 when compared against Group 1. Methanolic extract at lower dose offered significant ( $\mathrm{P}$ $<0.001)$ cardio-protection as evidenced by decreased Total protein levels. 
Urea

Results of effect of plant extract on urea levels are presented in Figure 11. Urea levels were found to be $24.32 \pm 4.866 \mathrm{mg} / \mathrm{dl}$ in the disease control group subjected to ISO. Significant increase in Urea levels was observed in Group 2 when compared against Group 1. Aqueous and Methanolic plant extracts of Jingini at lower dosages offered significant $(\mathrm{P}<0.001)$ cardio-protection as evidenced by decreased Urea levels.

\section{Histopathology of Heart}

One Rat from each group was subjected to light ether anesthesia. Once the animal becomes sluggish and minimizes its activity, a straight-line incision is done throughout its ventral part with the help of scalpel. The tissues are separated, and Heart is dissected out and was washed with running water and the buffer solution and was stored in formalin filled containers for the histopathological analysis. Figure 12-17

Table 1: Parameters assessed for Acute oral toxicity study (Motor Functions)

\begin{tabular}{|c|c|c|c|c|c|c|c|c|c|c|}
\hline \multicolumn{2}{|c|}{ Signs and Symptoms } & Basal & 30 min & $1 \mathrm{~h}$ & $2 \mathrm{~h}$ & $3 \mathbf{h}$ & $4 \mathrm{~h}$ & $24 \mathrm{~h}$ & $48 \mathrm{~h}$ & $72 \mathrm{~h}$ \\
\hline \multicolumn{2}{|c|}{ General impression } & $\mathrm{N}$ & $\mathrm{N}$ & $\mathrm{N}$ & $\mathrm{N}$ & $\mathrm{N}$ & $\mathrm{N}$ & $\mathrm{N}$ & $\mathrm{N}$ & $\mathrm{N}$ \\
\hline \multicolumn{2}{|c|}{ Increased motor activity } & - & - & - & - & - & - & - & - & - \\
\hline \multicolumn{2}{|c|}{ Convulsion: Tonic } & - & - & - & - & - & - & - & - & - \\
\hline \multicolumn{2}{|c|}{ Clonic } & - & - & - & - & - & - & - & - & - \\
\hline \multicolumn{2}{|c|}{ Straubs reaction } & - & - & - & - & - & - & - & - & - \\
\hline \multicolumn{2}{|c|}{ Muscle spasm } & - & - & - & - & - & - & - & - & - \\
\hline \multicolumn{2}{|c|}{ Catatonia } & - & - & - & - & - & - & - & - & - \\
\hline \multicolumn{2}{|c|}{ Opisthotonus } & - & - & - & - & - & - & - & - & - \\
\hline \multicolumn{2}{|c|}{ Hyperaesthesia } & - & - & - & - & - & - & - & - & - \\
\hline \multicolumn{2}{|c|}{ Decreased motor activity } & - & - & - & - & - & - & - & - & - \\
\hline \multicolumn{2}{|c|}{ Muscle relaxation } & - & - & - & - & - & - & - & - & - \\
\hline \multicolumn{2}{|c|}{ Anaesthesia } & - & - & - & - & - & - & - & - & - \\
\hline \multicolumn{2}{|c|}{ Arching and rolling } & - & - & - & - & - & - & - & - & - \\
\hline \multicolumn{2}{|c|}{ Lacrimation } & - & - & - & - & - & - & - & - & - \\
\hline \multicolumn{2}{|c|}{ Diarrhoea } & - & - & - & - & - & - & - & - & - \\
\hline \multicolumn{2}{|c|}{ Writhing } & - & - & - & - & - & - & - & - & - \\
\hline \multirow[t]{2}{*}{ Salivation } & Viscid & - & - & - & - & - & - & & - & - \\
\hline & Watery & - & - & - & - & - & - & & - & - \\
\hline \multirow[t]{3}{*}{ Respiration } & Stimulation & - & - & - & - & - & - & & - & - \\
\hline & Depression & - & - & - & - & - & - & & - & - \\
\hline & Failure & - & - & - & - & - & - & & - & - \\
\hline \multirow[t]{3}{*}{ Skin colour } & Blanching & - & - & - & - & - & - & & - & - \\
\hline & Cyanosis & - & - & - & - & - & - & & - & - \\
\hline & Vasodilatation & - & - & - & - & - & - & & - & - \\
\hline \multicolumn{2}{|c|}{ Grip strength } & $\mathrm{N}$ & $\mathrm{N}$ & $\mathrm{N}$ & $\mathrm{N}$ & $\mathrm{N}$ & $\mathrm{N}$ & $\mathrm{N}$ & $\mathrm{N}$ & $\mathrm{N}$ \\
\hline \multicolumn{2}{|c|}{ Visual placing response } & $\mathrm{N}$ & $\mathrm{N}$ & $\mathrm{N}$ & $\mathrm{N}$ & $\mathrm{N}$ & $\mathrm{N}$ & $\mathrm{N}$ & $\mathrm{N}$ & $\mathrm{N}$ \\
\hline \multicolumn{2}{|c|}{ Tail pinch response } & $\mathrm{N}$ & $\mathrm{N}$ & $\mathrm{N}$ & $\mathrm{N}$ & $\mathrm{N}$ & $\mathrm{N}$ & $\mathrm{N}$ & $\mathrm{N}$ & $\mathrm{N}$ \\
\hline \multicolumn{2}{|c|}{ Auditory response } & $\mathrm{N}$ & $\mathrm{N}$ & $\mathrm{N}$ & $\mathrm{N}$ & $\mathrm{N}$ & $\mathrm{N}$ & $\mathrm{N}$ & $\mathrm{N}$ & $\mathrm{N}$ \\
\hline \multicolumn{2}{|c|}{ mucus membrane } & $\mathrm{N}$ & $\mathrm{N}$ & $\mathrm{N}$ & $\mathrm{N}$ & $\mathrm{N}$ & $\mathrm{N}$ & $\mathrm{N}$ & $\mathrm{N}$ & $\mathrm{N}$ \\
\hline \multicolumn{2}{|c|}{ Pilo erection } & $\mathrm{N}$ & $\mathrm{N}$ & $\mathrm{N}$ & $\mathrm{N}$ & $\mathrm{N}$ & $\mathrm{N}$ & $\mathrm{N}$ & $\mathrm{N}$ & $\mathrm{N}$ \\
\hline
\end{tabular}

Table 2: Parameters assessed for Acute Toxicity studies (Higher Mental Functions)

\begin{tabular}{|c|c|c|c|c|c|c|c|c|c|c|c|c|c|c|c|c|}
\hline \multirow{2}{*}{$\underset{\Xi}{\stackrel{\Xi}{\Xi}}$} & \multirow{2}{*}{ 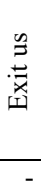 } & \multicolumn{5}{|c|}{ CNS Depression } & \multicolumn{2}{|c|}{ ANS } & \multicolumn{6}{|c|}{ CNS Stimulation } & \multirow{2}{*}{ 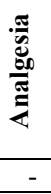 } & \multirow{2}{*}{ 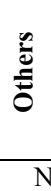 } \\
\hline & & - & - & - & - & - & - & - & - & - & - & - & - & - & & \\
\hline $1 \mathrm{~h}$ & - & - & - & - & - & - & - & - & - & - & - & - & - & - & - & $\mathrm{N}$ \\
\hline $4 \mathrm{~h}$ & - & - & - & - & - & - & - & - & - & - & - & - & - & - & - & $\mathrm{N}$ \\
\hline & & & & & & & & & & & & & & & & \\
\hline $24 \mathrm{~h}$ & - & - & - & - & - & - & - & - & - & - & - & - & - & - & - & $\mathrm{N}$ \\
\hline $48 \mathrm{~h}$ & - & - & - & - & - & - & - & - & - & - & - & - & - & - & - & $\mathrm{N}$ \\
\hline $72 \mathrm{~h}$ & - & - & - & - & - & - & - & - & - & - & - & - & - & - & - & $\mathrm{N}$ \\
\hline
\end{tabular}

Table 3: Abbreviation appreciations

\begin{tabular}{|c|c|}
\hline Abbreviations & Expansion \\
\hline ALT/SGPT & Alanine Aminotransferase \\
\hline ANS & Autonomic Nervous System \\
\hline AST/SGOT & Aspartate Aminotransferase \\
\hline CK & Creatinine Kinase \\
\hline CNS & Central Nervous System \\
\hline CPCSEA & The Committee for the Purpose of Control and Supervision on Animals \\
\hline CVD & Cardio Vascular Deaths \\
\hline HDL & High Density Lipoprotein \\
\hline
\end{tabular}


Rachana K.L. et al / Int. J. Res. Ayurveda Pharm. 11 (6), 2020

\begin{tabular}{|c|c|}
\hline IAEC & Institutional Animal Ethical Committee \\
\hline ISO & Isoproterenol \\
\hline LDH & Lactate Dehydrogenase \\
\hline MI & Myocardial Infarction \\
\hline SD Rats & Sprague Dawley Rats \\
\hline TP & Total protein \\
\hline
\end{tabular}

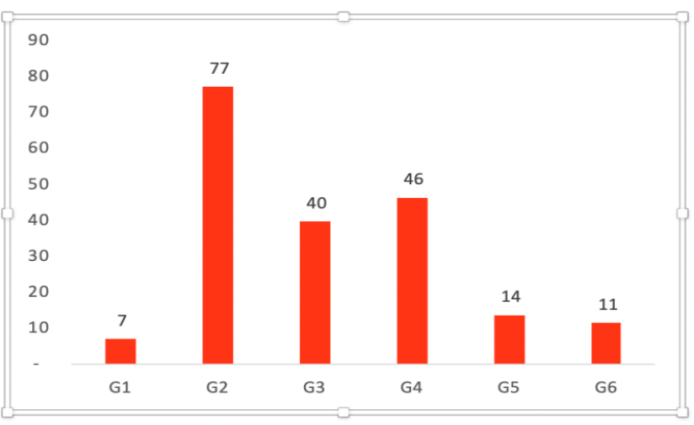

Figure 1: Average values of Creatinine Kinase MB

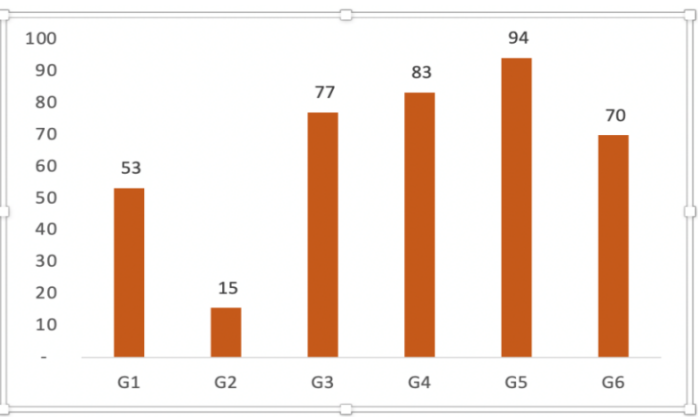

Figure 3: Average values of High density lipoprotein in mg/dl

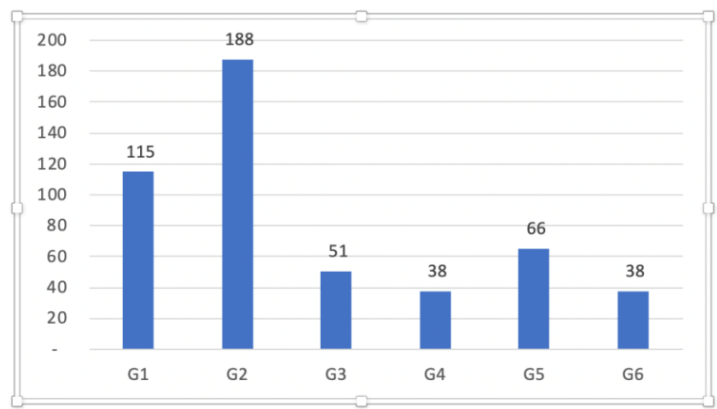

Figure 5: Average values of triglycerides

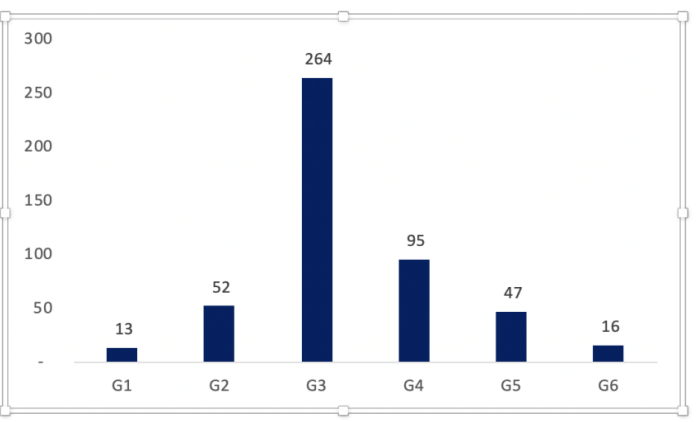

Figure 7: Average value of Aspartate transaminase

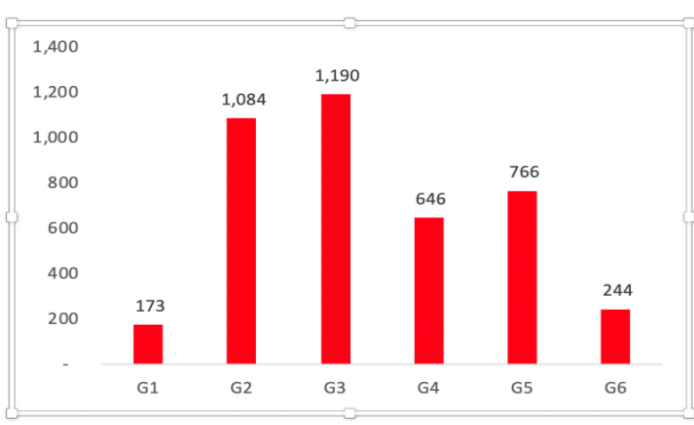

Figure 2: Average values of Lactase Dehydrogenase

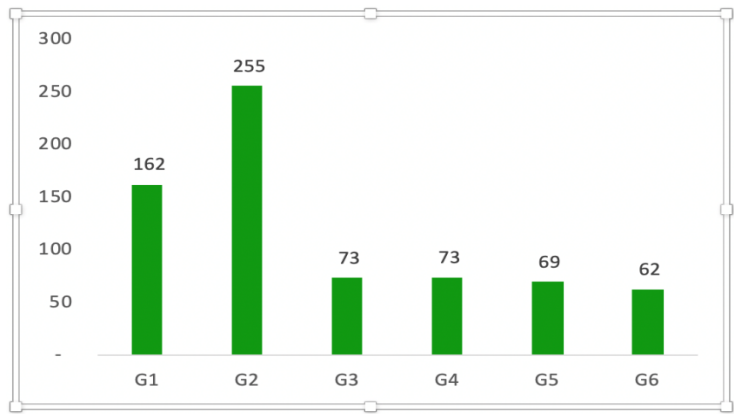

Figure 4: Average values of Cholesterol

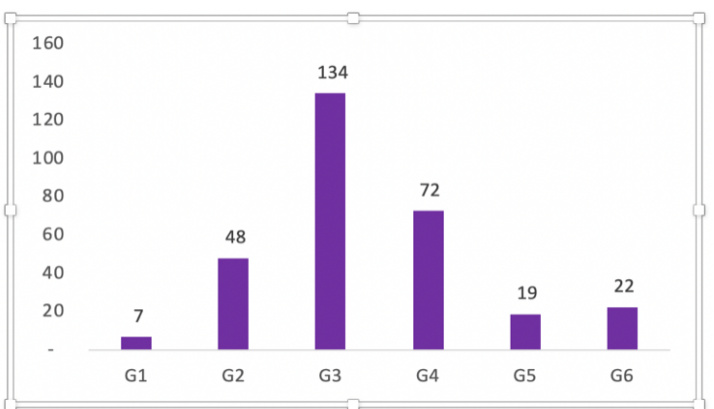

Figure 6: Average values of Alanine Transaminase

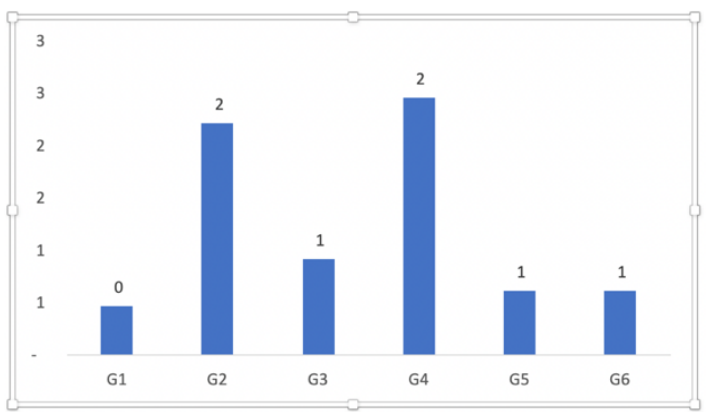

Figure 8: Average Values of Bilirubin in $\mathrm{mg} / \mathrm{dL}$ 


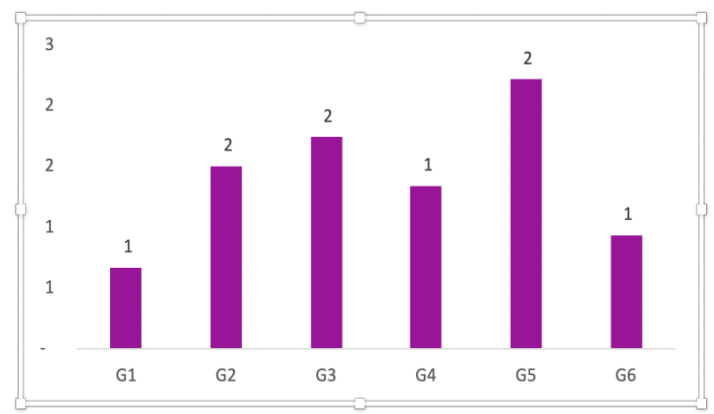

Figure 9: Average values of creatinine

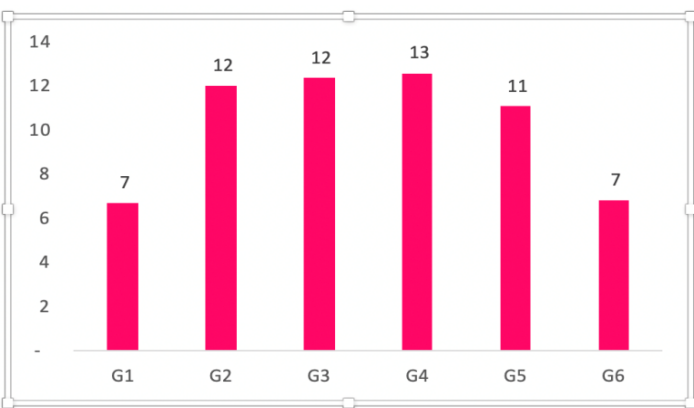

Figure 10: Average values of Total protein in g/dL

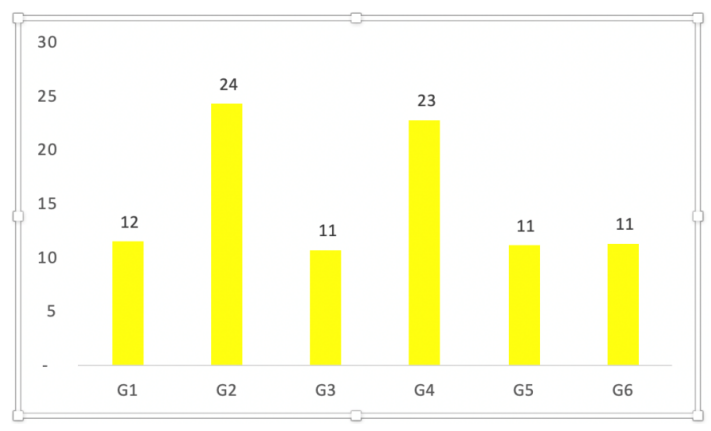

Figure 11: Average values of Urea in $\mathrm{mg} / \mathrm{dl}$

\section{Histopathology of Heart}

Groups:

Description:

G1 H ISO Model Control group

G2 H ISO Model Disease Control Group

\section{H\&E-100X.}

The histoarchitecture presentation of the heart tissue showed for the presence of normal architecture of myocytes with fibres. Lesions in the heart tissue was unremarkable with characteristic Normal cardiac myocytes with regular cross-striations and normal cellular density were observed..

The histoarchitecture presentation of the heart tissue showed for the myofibre dilatation throughout the tissue section. The cellular arrangement was moderate to severely derange when compared to control tissues. No lesions of Isoproterenol induced necrosis, apoptosis nor MNC infiltration was observed H\&E-100X.

G3 H Aqueous extract High Dose
The histoarchitecture presentation of the heart tissue showed for the presence of Isoproterenol induced moderate to severe multifocal necrosis, apoptosis and Mono Nuclear Cells including macrophage infiltration was observed. The lesional tissue also showed for the presence of hyper contraction bands with partial loss of basement membrane with interstitial infiltration.
Histopathology Images:

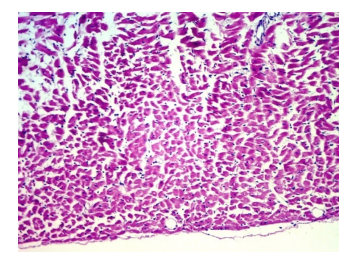

Figure 12

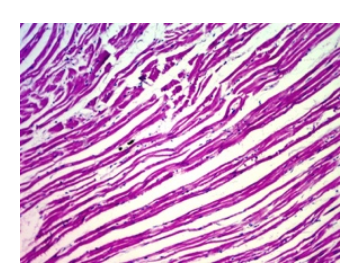

Figure 13

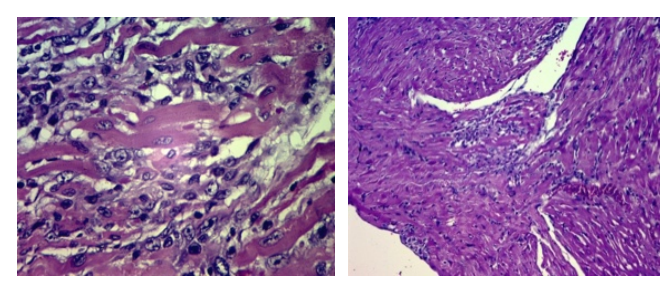

Figure 14 


\begin{abstract}
G4 H Aqueous The histoarchitecture presentation of the heart extract Low Dose tissue showed for the presence moderate to severe multifocal necrosis, apoptosis and Mono Nuclear Cells including macrophage infiltration was observed. The lesional tissue also showed for the presence of hyper contraction bands with partial loss of

basement membrane with interstitial infiltration. Sub endocardial fibrosis and necrosis was observed with mild to moderate intensity.
\end{abstract}

G5 H Methanolic extract High Dose

G6 H Methanolic extract Low Dose
The histoarchitecture presentation of the heart tissue showed for the presence of normal architecture of myocytes with fibres. Lesions in the heart tissue was unremarkable with characteristic Normal cardiac myocytes with regular cross-striations and normal cellular density were observed.

The histoarchitecture presentation of the heart tissue showed for the presence of normal architecture of myocytes with fibres. Lesions in the heart tissue were unremarkable with characteristic Normal cardiac myocytes with regular cross-striations and normal cellular density were observed.

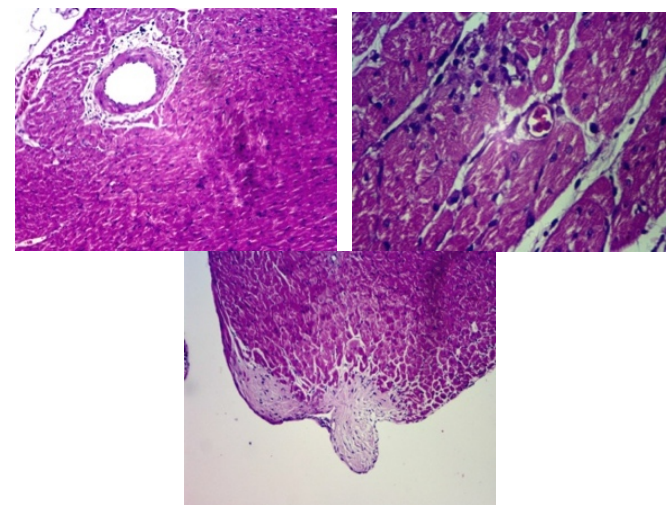

Figure 15

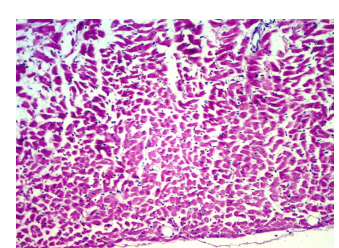

Figure 16

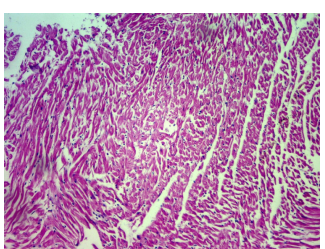

Figure 17

\section{DISCUSSION}

\section{Toxicity Study}

The Acute Oral Toxicity studies were conducted in accordance with OECD 425. There was no toxicity observed on administration of $5000 \mathrm{mg} / \mathrm{kg}$ Body weight. Henceforth $1 / 10^{\text {th }}$ and $1 / 5^{\text {th }}$ of $5000 \mathrm{mg} / \mathrm{kg}$ body weight was considered as Low and High Dose respectively. $1 / 10^{\text {th }}$ of $5000 \mathrm{mg} / \mathrm{kg}$ Body weight is 500 $\mathrm{mg} / \mathrm{kg}$ body weight which contributes to Low dose in the experimental study and $1 / 5^{\text {th }}$ of $5000 \mathrm{mg} / \mathrm{kg}$ body weight is 1000 $\mathrm{mg} / \mathrm{kg}$ body weight contributed to High dose of experimental study.

\section{Cardio-protective Activity Model}

In order to evaluate cardioprotective activity of Jingini - Lannea coromandelica Merr., (Hout), Isoproterenol Induced Cardiac toxicity model was chosen. ISO is a synthetic catecholamine and beta-adrenergic agonist. Its property to induce Myocardial Infarction in experimental animal is probably due to its action on the sarcolemma membrane, stimulation of adenylate cyclase, activation of $\mathrm{Na}^{+} \& \mathrm{Ca}^{2+}$ channels, exaggerated $\mathrm{Ca}^{2+}$ inflow and energy consumption leading to cellular death. ISO produces relative Ischemia or Hypoxia to myocardial hyperactivity and coronary Hypotension and induce Myocardial Ischemia due to systolic $\mathrm{Ca}^{2+}$ overload. ${ }^{7}$ Therefore Isoproterenol induced Cardiac toxicity model is most commonly used experimental model.

\section{Analysis of Biochemical Parameters}

The trial drug namely Aqueous and Methanolic extract of Stem Bark of Jingini-Lannea coromandelica, out of which Methanolic extract High and Low dose was proved to be successful in protecting the heart against Isoproterenol induced cardiac toxicity. Thus, the CKMB markers in the Serum of SD rats of Group $5 \& 6$ was maintained in the Optimum range which also meant that there was no hypoxia created at the level of Cardiomyocytes prolonging the Circulation to Heart by staving off the possibility of Myocardial damage.

The HDL levels in all trial groups are seen statistically significant in both the Models which indicate that Jingini has protected the Heart against the induced threat; whereas Total Cholesterol and Triglycerides were also found Significant statistically in all the trial group of both the models.

The SGPT, SGOT and Bilirubin were taken as supporting parameters for the drug safety systemically. Methanolic and Aqueous extract group in low dose shows high statistical significance in all the parameters indicating efficacy of the drug to provide the intended action without causing any Hepatotoxicity. Higher dose in both the extracts have increased the levels of the parameters when compared to disease control, this indicates drug in higher doses might be efficacious in the intended action but might cause Hepatotoxicity. 
The Creatinine and Urea parameters were taken as supporting data for the systemic safety profile of the drug. Methanolic and Aqueous extract group in low dose shows high statistical significance in all the parameters indicating efficacy of the drug to provide the intended action without causing any Renal Toxicity. Higher dose in both the extracts have increased the levels of the parameters when compared to disease control, this indicates drug in higher doses might be efficacious in the intended action but might cause renal toxicity.

\section{Histopathology of Heart}

The histopathology of the Aqueous extract both the models indicates Mild to severe damage to muscle fibres and cardio myocytes. This indicates Jingini in aqueous form did not show Intended action may be due to insufficient solubility of Phyto constituents in the extract. The histopathology of the Methanolic extract of both models indicates zero to mild damage to muscle fibres and Cardiomyocytes. This indicates Jingini in Methanolic extract form did show the intended action due to the better solubility of Phyto constituents in the extracts prepared.

\section{Mode of action of JINGINI in Hridroga}

Shoshana property of Kashaya rasa counters the dravata of Pitta, kapha dosha and Medo dhatu. Ruksha Guna of Kashaya rasa counters the kledata of Kapha Dosha and Medo dhatu. Madhura rasa counters pitta dosha and also pacifies the Trishna Lakshana of Hridroga. Kashaya rasa has Kapha Pitta Rakta hara property. Hridayaamaya is the one among Kaphaja Nanatmaja Vyadhis, since Kashaya rasa has Kapha hara property it counters the vyadhi. Ushna veerya counters Kapha and Medas, Regulates Ama Pachana. Tikshna Guna has Vivrunoti Karma hence does Vivrunoti of Dhamanis. Due to the above mentioned Gunas and respective karmas attributed, Jingini does Samprapti Vighatana of Hridroga. ${ }^{8}$

\section{Mode of Action of Phytoconstituents of Jingini in Hridroga}

Alkaloids are proved for certain pharmacological activity such as; Analgesic, Antihypertensive, Anti arrhythmic, CNS stimulants and Vasodilators. Such actions are found to be in relation with the cardioprotective activity of Jingini. The Alkaloids might act against the negative manipulations happening in the Cardiovascular system particularly heart due to induction of Cardiac toxicity through Isoproterenol. Since Alkaloids act as Analgesics, they might act against severe Chest pain experienced during Myocardial Ischemia or Infarction and help reduce the pain. They maintain the circulation throughout the Cardiac muscle and Cardiomyocytes due to their Vasodilating action and also protect heart from abnormal beating due to its Anti arrhythmic activity. Henceforth can also maintain optimum range of Arterial blood pressure thereby achieving the Homeostasis of the cardiovascular system. ${ }^{9}$ Flavonoids are a class of poly phenol secondary metabolite which are broadly present in plants and are known to have various biological activities such as; Anti-inflammatory, Anti- viral, Cardioprotective. ${ }^{10}$ Hence contributing towards the experimental evaluation. Polyphenols are majorly known for its Antioxidant activity which has major contribution in inhibiting complication of cardiovascular disease particularly myocardial infarction ${ }^{11}$. Therefore, its performance is mainly seen against the free radical damage caused due to induction of Cardiac toxicity through Isoproterenol. ${ }^{11}$ Tannins are majorly known for their Hemostatic, Anti-septic and Toning activities which protects the layer of the skin. Though the Tannins do not contribute majorly towards the cardiac activity, since they are also considered to be antioxidants $^{12}$, they contribute against the oxidative stress damage of Cardiomyocytes caused due to cardiac toxicity upon inducing Isoproterenol.

\section{CONCLUSION}

The present study reinforces the thought of Bhavamishra of Jingini being upheld in Hridroga. Experimental evaluation emphasizes the Jingini being Cardio-protective. The Phytochemicals such as Alkaloids, Flavonoids, Polyphenols and Tannins of Jingini are responsible for its Cardio-protective activity. The presence of Shoshana karma, Ruksha Guna in Kashaya Rasa, Pittaghna and Balya of Madhura rasa, Tikshna Guna and Ushna Veerya of Jingini interferes in Samprapti of Hridroga.

\section{Further scope of study}

Jingini - Lannea coromandelica Merr. (Houtt) should be further explored for various cardiovascular diseases experimentally and clinically. Further, subacute and long-term toxicity studies has to be conducted in order to complete the safety profile of Jingini with respect to Cardio protective activity.

\section{ACKNOWLEDGEMENT}

I would like to convey my whole hearted regards to Principal, Acharya and BM Reddy College of Pharmacy, Bangalore, for permitting me to utilise the Lab and Library facilities of the College. I would like to thank Dr Suresh Janadri, Assistant professor, Department of Pharmacology, Acharya and BM Reddy College of Pharmacy, Bangalore for his continuous support and guidance throughout the study duration. Token of gratitude to Dr Kamrudeen Samani, Research scholar, Acharya and BM Reddy College of Pharmacy

\section{REFERENCES}

1. Madhavakara: Madhava Nidanam. Tripathi Brahmanand editor. Vimala: Madhudhara Hindi commentary - Vol 1. Varanasi: Chaukhambha Surbharati Prakashan; 2010. p. 61415 .

2. Madhavakara, Madhava Nidanam. Tripathi Brahmanand editor. Vimala: Madhudhara Hindi commentary - Vol 1. Varanasi: Chaukhambha Surbharati Prakashan; 2010. p. 61419.

3. Sharma Kumar Ajay. Kaya Chikitsa Vol II. Varanasi: Chaukhambha Orientalia; 2014. p. 16-34.

4. Prabhakaran, D., P. Jeemon, A. Roy. Cardiovascular Diseases in India: Current Epidemiology and Future Directions. Global burden of cardiovascular disease 2016; 133: 1605-20.

5. Sahoo N, Manchikanti P. Herbal Drug Regulation and Commercialization: An Indian Industry Perspective. J Altern Complement Med 2013 Dec 1; 19(12): 957-63.

6. H. Gerhard Vogel. Drug Discovery and Evaluation, Pharmacological Assays. 2 ${ }^{\text {nd }}$ ed. Springer Heidelberg Publishers; 2002. p. 180.

7. Rimal Nikesh. Evaluation of Cardioprotective effect of Thuja occidentalis L. leaves against Isoproterenol Induced Myocardial Infarction in Rats. Karnataka: Rajiv Gandhi university of Health Sciences: May-June 2018.

8. Agnivesha, Charaka, Dridhabala, Charaka Samhita. Sutra Sthana 25/20. Kushwaha HS editor. Reprint ed. Varanasi: Chaukhambha Orientalia; 2011. p. 620-23.

9. Raymond S. Sinatra, Jonathan S. Jahr; J. Michael WatkinsPitchford. The essence of Analgesia and Analgesics. Cambridge University Press; 2010. p. 82-90.

10. Wang Yang Tian, Bi Shun-Kai. Bioactive Flavonoids in Medicinal Plants: Structure, activity and biological fate. 
Asian Journal of Pharmaceutical sciences Jan 2018; 13: 1223.

11. Nuttall S.L, Kendall M.J, Martin U. Antioxidant Therapy for the Prevention of Cardiovascular Disease. QJM: An Int Journal of Medicine May 1999; 92(5): 239-44.

12. Calixto J.B, Nicolau M, Rae G.A. Pharmacological Actions of Tannic Acid I. Effects on Isolated Smooth and Cardiac Muscles and on Blood Pressure. PubMed.gov. Feb 1986; 1: 32-35.

\section{Cite this article as:}

Rachana K.L. et al. An experimental study to evaluate cardioprotective activity of Jingini Lannea coromandelica Merr (Houtt): An In Vivo Study. Int. J. Res. Ayurveda Pharm. 2020;11(6):37-46 http://dx.doi.org/10.7897/2277-4343.1106182

\section{Source of support: Nil, Conflict of interest: None Declared}

Disclaimer: IJRAP is solely owned by Moksha Publishing House - A non-profit publishing house, dedicated to publishing quality research, while every effort has been taken to verify the accuracy of the content published in our Journal. IJRAP cannot accept any responsibility or liability for the site content and articles published. The views expressed in articles by our contributing authors are not necessarily those of IJRAP editor or editorial board members. 